\title{
Sprawozdanie z pobytu w Oddziale Bundesarchiv w Ludwigsburgu w ramach programu stypendialnego EHRI
}

W dniach 25 czerwca - 1 lipca 2018 r. przebywałam w Ludwigsburgu, pracując nad wstępną kwerendą do projektu pod roboczym tytułem „Sprawa Heinricha Hamanna - szefa nowosądeckiego gestapo - lata 1960-1966" w zasobie Oddziału Bundesarchiv w Ludwigsburgu. Rozpoczęcie poszukiwań było możliwe dzięki finansowaniu badań z projektu stypendialnego European Holocaust Research Infrastructure - EHRI Fellowship 2016-2018.

Oddział Bundesarchiv w Ludwigsburgu przechowuje materiały archiwalne przejmowane z Centrali Badania Zbrodni Narodowosocjalistycznych w Ludwigsburgu (Zentrale Stelle der Landesjustizverwaltungen zur Aufklärung nationalsozialistischer Verbrechen). Instytucja ta powstała 1 grudnia 1958 r., a jej celem jest badanie zbrodni nazistowskich, szczególnie prowadzenie śledztw i zbieranie dowodów procesowych przeciwko nazistowskim zbrodniarzom wojennym. Mimo wielu kontrowersji związanych z jej funkcjonowaniem wykonuje swoje zadania statutowe do dziś. Należy do nich także wytwarzanie i przechowywanie dokumentacji w formie akt poszczególnych postępowań. W zadaniu archiwizowania materiałów archiwalnych procesów zakończonych, a więc dokumentacji, która nie jest już potrzebna do bieżącej działalności, od 2000 r. wspomaga instytucję Bundesarchiv. Jego placówkę zorganizowano w tym samym budynku, w którym zlokalizowana jest siedziba Centrali (Schorndorfer Str. 58) ${ }^{1}$.

Projekt dotyczący procesu Heinricha Hamanna jest efektem współpracy pracowników Archiwum Narodowego w Krakowie Oddział w Nowym Sączu z gronem historyków związanych z inicjatywą Sądeckiego Sztetlu (współtworzoną przez Fundację Nomina Rosae w Nowym Sączu i Pedagogiczną Biblioteką Wojewódzką w Nowym Sączu). Idea przeprowadzenia kwerendy w aktach z procesu szefa nowosądeckiego gestapo toczącego się przed Sądem Rejonowym w Bochum narodziła się w 2016 r., a poszukiwania w zasobie Oddziału w Ludwigsburgu są pierwszym jej etapem. Ich celem jest odnalezienie nowych źródeł do tematyki związanej z historią i eksterminacją sądeckich Żydów, np. zeznań świadków.

H. Hamann (ur. 1 września 1908 r. w Bordesholm, zm. 16 kwietnia 1993 r.), szef Zamiejscowej Placówki Policji Bezpieczeństwa - Granicznego Komisariatu Policji (sądeckiego gestapo) od września 1939 r. do sierpnia 1943 r., był odpowiedzialny za eksterminację Żydów na Sądecczyźnie i masowe egzekucje. Został oskarżony o własnoręczne zamordowanie ok. 100 osób. Po wojnie ukrywał się pod fałszywym nazwiskiem w RFN, gdzie pracował m.in. jako kelner. 5 maja 1960 r. w restauracji w Bochum po kłótni z klientem zabił go strzałem z pistoletu. Został aresztowany i wkrótce zdemaskowany jako nazistowski

${ }^{1}$ Jens Romme1, Einzigartige Zusammenabeit von Ermittlern und Archivaren in Ludwigsburg, „Forum. Das Fachmagazin des Bundesarchivs. Das Bundesarchiv geht Alle an“ 2017, s. 28. 
zbrodniarz wojenny. W procesie toczącym się w Bochum (18 października 1965 - 20 lipca 1966 r.) skazano go na dożywocie ${ }^{2}$.

H. Hamann zapisał się niechlubnie w historii Nowego Sącza i całego regionu sądeckiego, zwłaszcza w stosunku do Żydów, którzy tu przed wojną żyli. Po dziś dzień można spotkać ludzi, którzy go pamiętają.

Głównym celem mojej wizyty było przeprowadzenie wstępnej kwerendy związanej z procesem H. Hamanna. Planowałam zapoznać się z dokumentami zgromadzonymi w postępowaniu przygotowawczym prowadzonym w jego sprawie przez Centralę, a szczególnie wyselekcjonować te związane z tematyką Holokaustu w Nowym Sączu.

Podczas kwerendy zapoznałam się z 14 jednostkami aktowymi z zespołu B 162 (sygn. B 162/1369-1975, 1378-1382, 14220, 14273). Były to głównie zeznania świadków: Żydów, którym udało się przeżyć Holokaust, ale także H. Hamanna oraz jego współpracowników. Źródła te, sporządzone w formie maszynopisów w języku niemieckim, w większości nie są w ogóle znane lokalnym historykom zajmującym się tą tematyką. Zeznania dotyczą w dużej mierze faktów powszechnie znanych, takich jak: akcja kwietniowa (28 kwietnia 1942 r.) - masowy mord na Żydach pod pretekstem poszukiwania członków partii komunistycznej oraz związane z tym zabójstwo Augusta Koestera, współpracownika H. Hamanna; akcja likwidacji getta sądeckiego, czy też masowy mord na kirkucie w Nowym Sączu. Można się z nich ponadto dowiedzieć, jak wyglądało życie codzienne w okupowanym mieście zarówno z punktu widzenia oprawców, jak i ofiar.

W trakcie pobytu miałam także okazję przyjrzeć się, jak zorganizowane jest udostępnianie akt w czytelni Oddziału, zwiedziłam część magazynową, a także uzyskałam szczegółowe informacje na temat oferty edukacyjnej prowadzonej przez placówkę.

Podsumowując, podkreślam, że moja wizyta w Oddziale Bundesarchiv w Ludwigsburgu miała charakter rozpoznawczy, a kwerenda powinna być kontynuowana, aby osiągnąć cele projektu, a więc: wyselekcjonowanie dokumentów źródłowych związanych z tematem Holokaustu w Nowym Sączu i na Sądecczyźnie, pozyskanie ich kopii oraz udostępnienie ich dla użytkowników odwiedzających czytelnię Oddziału w Nowym Sączu oraz wykorzystanie do celów edukacyjno-popularyzacyjnych.

2 Jerzy Leśniak, Nowa encyklopedia sądecka, Nowy Sącz 2017, s. 245. 